\title{
Penguatan Karakter Melalui Strategi Wisdom Massage pada Generasi Milenial
}

\section{Retno Fajarwati}

\author{
SMA Negeri 1 Sidoharjo \\ retno743@yahoo.co.id
}

\section{Article History}

accepted 01/02/2020

approved 01/03/2020

published 01/04/2020

\begin{abstract}
Character education is interpreted as education that develops the nation's character in students, in this case students so that they have values and character in themselves and are able to implement these values in daily life both as members of society and citizens who are religious, nationalist, productive and creative. Character is a form of character, character, character inherent in a person's personality which is formed from the results of internalization that is used as a basis for thinking and behaving so as to cause a characteristic to the individual. Millennial generation that is addicted to the internet tends to decrease the desire to communicate directly, face to face, especially with family. More than that, the internet actually has limited the association of a millennial teenager. Millennials who are addicted to the internet can only relate to those who are also able to access the internet. Millennial neration can still socialize well and has a strong character that is the wisdom massage strategy. .
\end{abstract}

Keywords: millennial generation, character strengthening, wisdom massage.

\section{Abstrak}

Pendidikan karakter dimaknai sebagai pendidikan yang mengembangkan karakter bangsa pada diri peserta didik dalam hal ini mahasiswa sehingga mereka memiliki nilai dan karakter dalam dirinya serta mampu mengimplementasikan nilai-nilai tersebut dalam kehidupan sehari-hari baik sebagai anggota masyarakat maupun warganegara yang religius, nasionalis, produktif dan kreatif.Karakter adalah bentuk watak, tabiat, akhlak yang melekat pada pribadi seseorang yang terbentuk dari hasil internalisasi yang digunakan sebagai landasan untuk berpikir dan berperilaku sehingga menimbulkan suatu ciri khas pada individu tersebut.Generasi millenial yang kecanduan internet cenderung mengalami penurunan keinginan untuk berkomunikasi secara langsung, tatap muka, khususnya dengan keluarga.Lebih dari itu, sebenarnya internet telah membatasi pergaulan seorang remaja millenial.Remaja millenial yang kecanduan internet hanya bisa berelasi dengan mereka yang juga mampu mengakses internet.Perlu adanya pembanding agar generasi milenial tetap dapat bersosialisasi dengan baik dan berkarakter kuat yaitu dengan strategi wisdom massage.

Kata kunci: generasi milenial, penguatan karakter, wisdom massage 


\section{PENDAHULUAN}

Perkembangan teknologi digital yang terjadi saat ini ditandai dengan penggunaan teknologi hampir dalam setiap aspek kehidupan.Teknologi telah menjadi bagian dari kehidupan kita sehari-hari.Berbagai kemudahan dapat dinikmati, mulai dari berbelanja, berkomunikasi, sampai pembelajaran yang kini semuanya dapat dilakukan secara on-line, tanpa harus membuang tenaga dan waktu.Teknologi muncul dengan berbagai macam jenis dan fitur baru dari hari ke hari.Kebutuhan teknologi merupakan salah satu kebutuhan penting saat ini.Hal ini disebabkan karena teknologi sangat dibutuhkan untuk banyak keperluan.Teknologi komunikasi memiliki perkembangan yang paling pesat.Perkembangan teknologi informasi dan komunikasi tersebut tanpa disadari sudah mempengaruhi setiap aspek kehidupan manusia. Karena dengan seiring arus globalisasi tuntutan kebutuhan pertukaran informasi yang cepat menyebabkan peranan teknologi komunikasi menjadi sangat penting., 2002). Dalam melayani siswa yang merupakan pemilik era milenial ini pendidik harus mampu mengembangkan media dan teknologi pembelajaran dengan baik.Kemajuan teknologi memberikan kemudahan di dalam dunia pendidikan terutama dalam mengembangkan media pembelajaran. Media pembelajaran yang dibuat selayaknya memperhatikan karakteristik siswa yang berhubungan denganmotivasi, bakat, minat, kemampuan awal, gaya belajar, dan kepribadian. Seperti yang diketahui bahwa ketersediaan sumber belajar sangat memengaruhi hasil belajar siswa. Metode pembelajaran inovatif juga penting dalam proses pembelajaran. Semakin baik metode pembelajaran yang dipakai oleh pendidik didukung oleh media pembelajaran yang menarik maka akan menciptakan suasana pembelajaran yang menggairahkan.

Komunikasi menggunakan gadget tentunya mengubah aturan yang sudah ada sebelumnya dan dapat membuat kualitas serta kuantitas komunikasi tatap muka menurun.Siswa dalam kehidupan seharihari memang tidak dapat lepas dari gadget. Gadget sebagai alat komunikasi dapat digunakan siswa dalam berkomunikasi tanpa ada batasan waktu, karena di tengah malam pun siswa dapat melakukan komunikasi dengan orang lain. Adapun dilingkungan sekolah keberadaan gadget dapat menjadi pola interaksi baru dalam berhubungan dengan siswa lain, siswa lebih memilih menggunakan gadget karena dianggap lebih praktis, efisien, memperpendek jarak dan mempercepat waktu serta memudahkan siswa dan tidak perlu repot datang ke tempat seseorang yang dimaksud. Siswa baru akan mendatangi/bertemu teman yang dimaksud apabila pesan yang disampaikan melalui gadget tidak tersampaikan atau tidak terkirim. Hal inimenunjukkan bahwa gadget telah digunakan sebagai cara baru interaksi sosial terutama bagi pengguna aktif gadget untuk bertemu dan berinteraksi dengan teman-teman mereka. Hal ini menunjukkan bahwa interaksi sosial di dunia maya dengan menggunakan gadget digemari oleh banyak orang dan telah mengubah cara berkomunikasi (Harfiyanto, dkk, 2015). Kehadiran gadget pun menjadikan perubahan perilaku siswa, dimana ketika siswa sedang bergerombol atau berkerumun untuk sekedar membicarakan suatu hal, tidak jarang mereka akan lebih asik dengan gadgetnya dari pada dengan orang yang ada didekatnya. Ketika sedang berjalan pun asik sambil memainkan gadgetnya.Siswa hanya menunduk menatap gadget tanpa menghiraukan lingkungan sekitar (Harfiyanto, dkk, 2015).Selain dapat digunakan untuk telepon dan pesan singkat seperti halnya telepon biasa, fasilitas dan kemudahan yang ada dalam smartphone, yang kemudian menarik para remaja untuk menggunakan handphone ini.Salah satu fitur yang menjadi kelebihan smartphone dari handphonehandphone lainnya adalah banyaknya fitur yang tersedia. Ini yang membuatsmartphone memiliki daya tarik yang cukup tinggi, seperti fasilitas chatting atau fasilitas percakapan singkat melalui WhatsApp, Line, Twitter, Instagram, Youtube, dan lain-lain (Yenni Yuniati, dkk, 2015:1). Dengan berbagai fasilitas ini, maka pengguna dapat mengirim pesan singkat, mengirim gambar, data, melakukan percakapan secara berkelompok atau conference, mengirimkan pesan suara maupun 
mengirimkan lokasi dimana kita berada.Fasilitas lain dari smartphone misalnya, fasilitaspush e-mail (mengirimkan pesan elektronik dengan jaringan internet), browsing (penjelajahan dunia maya dengan jaringan internet), hiburan seperti pemutaran musik maupun video, kamera dan juga kemampuan penyimpanan data yang hampir mirip seperti yang terdapat pada komputer (Yenni Yuniati, dkk, 2015:1). Berdasarkan uraian di atas dapat disimpulkan bahwa penggunaan gadget digunakan tanpa batasan waktu, bisa saat di sekolah maupun di rumah, dan di tempat lain, cara yang digunakan siswa bisa dengan cara sambil mengobrol, sambil berjalan, saat berkerumun, dan lain sebagainya. Fungsi atau kegunaan gadget dianggap menjadi pola interaksi baru dalam berhubungan dengan siswa lain, siswa lebih memilih menggunakan gadget karena dianggap lebih praktis, efisien, memperpendek jarak dan mempercepat waktu serta memudahkan siswa dan tidak perlu repot datang ke tempat seseorang. Aplikasi yang digunakan juga bermacam-macam seperti whatsapp, LINE, BBM, facebook, videocall, dan lain sebagainya.Secara sosial. Menurut dr. Neil aldrin, m.psi, psikolog, generasi alpha cenderung bersikap lebih pragmatis materialistic, karena dibesarkan di era kemajuan teknologi. Mereka juga berpikir dengan sangat praktis, kurang memerhatikan nilai-nilai, dan secara umum lebih egois di banding generasi-generasi sebelumnya. Kemajuan teknologi yang pesat ini pun ke depannya pasti akan mempengaruhi mereka: mulai dari gaya belajar, materi yang dipelajari di sekolah, sampai dengan pergaulan mereka sehari-hari.

Para remaja millenial sangat aktif membangun dunia kognitifnya.Mereka sudah mempunyai pola pikir sendiri alam menanggapi masalah, memilah-milah dan mengorganisir ide-ide dan menciptakan ide baru.Kemampuan remaja millenial dalam belajar, memori, menalar, berpikir dan bahasa sangat berkembang sehingga mereka dapat berpikir secara abstrak atau tentang sesuatu yang abstrak. Remaja millenial mampu berspekulasi. Mereka mulai mempertanyakan keabsahan pemikiran yang ada dan mempertimbangkan banyak alternatif pemikiran yang lain sehingga seringkali mereka mengalami konflik pemahaman. Internet dapat menjadi salah satu sarana remaja millenial memperoleh informasi serta jawaban-jawaban dari masalah yang dihadapi.Internet dapat memperluas wawasan berpikir remaja millenial. Akan tetapi, apabila seorang remaja millenial kecanduan internet, ia menjadi terikat pada internet. Internet lalu dijadikan satu-satunya sumber kebenaran. Seorang remaja millenial tidak lagi mampu membedakan hal-hal mana yang nyata dan hal-hal mana yang maya. Baginya yang maya juga nyata. Remaja millenial menjadi kehilangan pola pikirnya sendiri. Pola pikirnya sangat dipengaruhi pola pikir yang ada dalam internet. Masa remaja millenial merupakan masa yang penuh gejolak bagi remaja millenial. Ketegangan emosi meninggi karena adanya perubahan fisik dan kelanjar, pencarian identitas diri, serta konflik-konflik sosial. Selain itu, remaja millenial sangat rentan terhadap pendapat orang lain tentang dirinya. Remaja millenial sangat memperhatikan dirinya sendiri. Dalam diri remaja millenial juga mulai timbul rasa cinta dan kasih sayang terhadap oranglain, khususnya lawan jenis. Internet dapat membantu perkembangan emosi seorang remaja millenial. Remaja millenial dapat melampiaskan segala perasaan yang ada dalam dirinya dengan berbagai cara seperti lewat situs jejaring sosial, Facebook atau Twiter. Pada masa remaja millenial, seorang remaja millenial mulai melepaskan diri dari orang tua. Mereka mulai menyesuaikan diri dengan lawan jenis. Kelompok teman sebaya sangat berpengaruh dalam pergaulan remaja millenial. Internet dapat membantu remaja millenial dalam bersosialisasi. Internet memudahkan remaja millenial menjalin relasi dengan teman ataupun lawan jenis. Jarak dan waktu tidak lagi menjadi halangan dalam hal komunikasi.Akan tetapi, sebuah penelitian menggungkapkan bahwa seorang remaja millenial yang kecanduan internetcenderung mengalami penurunan keinginan untuk berkomunikasi secara langsung, tatap muka, khususnya dengan keluarga. Lebih dari itu, sebenarnya internet telah membatasi pergaulan seorang remaja millenial.Remaja millenial yang kecanduan 
internet hanya bisa berelasi dengan mereka yang juga mampu mengakses internet. Sudah tidak dipungkiri lagi, kehidupan kita sangat lekat dengan kemajuan teknologi, apalagi dikalangan remaja millenial yang sangat berpengaruh pada kemajuan teknologi suatu negara.Sekitar tahun 2000-an internet sudah mulai dikenal oleh masyarakat kita, dengan semakin banyak pengguna internet muncul lah jejaring-jejaring sosial. Semakin lama jejaring sosial berkembang sangat pesat, antara lain Facebook, Twitter, Friendster MySpace dan banyak lagi. Jejaring sosial mempunyai fungsi utama yaitu untuk menjalin pertemanan atau berhubungan dengan orang lain diseluruh dunia melalui akun di jejaringan sosial tanpa harus bertatap muka langsung dan menempuh jarak yang jauh. Jelas, kalangan remaja millenial lah yang pertama kali mengenal dan berlomba-lomba membuat akun dijejaring sosial yang disaat itu sedang mempunyai banyak pengguna.

Melihat dari fenomena tersebut, penulis yang merupakan guru PPKn sangat prihatin dan berupaya melakukan sesuatu hal untuk dapat mengatasinya. Penulis membuat pembanding agar para peserta didik menjadi balance dalam memanfaatkan teknologi dan dalam menggunakan smartphone yaitu dengan strategi wisdom massage.

\section{METODE}

Penelitian ini merupakan penelitian tindakan kelas (Classroom Action Research). Penelitian tindakan kelas adalah salah satu strategi pemecahan masalah yang memanfaatkan tindakan nyata dan proses pengembangan kemampuan dalam mendeteksi dan memecahkan masalah (Djunaidi, 2008:8). Penelitian ini menggunakan pendekatan kualitatif untuk memahami fenomena tentang apa yang dialami oleh subyek penelitian misalnya perilaku, persepsi, motivasi, tindakan, dan lain sebagainya, secara holistik (utuh) dan dengan cara deskriptif dalam bentuk kata-kata dan bahasa, pada suatu konteks khusus yang alamiah dan dengan memanfaatkan berbagai model pembelajaran alamiah (Lexi, 2011:6).

Jenis penelitian tindakan kelas (classroom action research) dilakukan oleh guru bekerja sama dengan peneliti atau dilakukan oleh guru sendiri yang juga bertindak sebagai peneliti di kelas atau di sekolah tempat ia mengajar dengan penekanan pada penyempurnaan atau peningkatan proses dan praktis pembelajaran. Penelitian tindakan kelas (PTK) (action research) dilakukan dengan tujuan memperbaiki mutu praktik pembelajaran di kelasnya. PTK berfokus pada kelas atau pada proses belajar mengajar yang terjadi di kelas. Sumber data menggunakan data primer dan data sekunder. Subjek penelitian ini adalah siswa SMA Negeri 1 Sidoharjo, Teknik pengumpulan data menggunakan wawancara, observasi dan dokumentasi.

\section{HASIL DAN PEMBAHASAN}

Karakter adalah bentuk watak, tabiat, akhlak yang melekat pada pribadi seseorang yang terbentuk dari hasil internalisasi yang digunakan sebagai landasan untuk berpikir dan berperilaku sehingga menimbulkan suatu ciri khas pada individu tersebut (Titin, 2008:682). Karakter individu akan berkembang dengan baik, apabila memperoleh penguatan yang tepat, yaitu berupa pendidikan. Pendidikan diharapkan mampu melahirkan masyarakat terdidik berakhlak mulia dan mampu meningkatkan kesadaran masyarakat untuk hidup secara harmonis, toleran dalam kemajemukan, berwawasan kebangsaan yang demokrasi serta berwawasan global seperti yang dijelaskan pada Pasal 3 Undang-Undang Nomor 20 Tahun 2003 tentang Sistem Pendidikan Nasional menyebutkan bahwa Pendidikan Nasional berfungsi mengembangkan kemampuan dan membentuk watak serta peradaban bangsa yang bermartabat dalam rangka mencerdaskan kehidupan bangsa.

Generasi milenial (juga dikenal sebagai Generasi Y) adalah kelompok demogra setelah Generasi X (Gen-X). Tidak ada batas waktu yang pasti untuk awal dan akhir 
dari kelompok ini. Para ahli dan peneliti biasanya menggunakan awal 1980-an sebagai awal kelahiran kelompok ini dan pertengahan tahun 1990-an hingga awal 2000-an sebagai akhir kelahiran. Milenial pada umumnya adalah anak-anak dari generasi Baby Boomers dan Gen-X yang tua. Milenial kadang-kadang disebut sebagai "Echo Boomers" karena adanya 'booming' (peningkatan besar) tingkat kelahiran di tahun 1980-an dan 1990- an.

Wisdom massage merupakan pesan bijak berupa kata-kata yang dapat dibuat oleh para pendidik dengan berbagai media. Pesan yang menyampaikan kesadaran dan penguatan karakter agar peserta didik dapat tetap membutuhkan lingkungannya walaupun hidup dalam teknologi. Pesan juga dapat dikampanyekan di lingkungan sekolah maupun melalui media sosial. Memberikan informasi melalui media sosial dengan memperlihatkan gejala Nomophobia yang secara tidak sadar pernah target alami dikehidupan sehari-hari. Melalui serangkaian kampanye ini diharapkan target dapat memahami dampak Nomophobia hingga muncul prilaku bijak menggunakan smartphone. Kesan "Fun and Friendly" yang akan dirasakan oleh target sehingga menggugah rasa penasaran dan ingin mengetahui lebih lanjut. Selain itu kesan friendly dimunculkan agar pesan tidak terkesan menggurui. Sesuai dengan tujuan perancangan yaitu untuk menumbuhkan kesadaran target mengenai dampak ketergantungan terhadap smartphone (Nomophobia). Perlu adanya informasi mengenai apa itu ketergantungan terhadap smartphone terlebih dahulu, lalu di susul dengan gejala dan dampaknya. Setelah itu target akan mendapatkan tips untuk meminimalisir gejala/dampak dari Nomophobia yang mereka alami. Pesan juga dapat dibuat dengan AISAS (Attention, Interest, Search, Action, Share) dipilih karena pesan ini memanfaatkan teknologi yang banyak di gandrungi pada saat ini seperti smartphone. Hampir setiap hari target bersentuhan dengan smartphone-nya, terutama media sosial yang hampir setiap waktu dapat diakses oleh target. Selain Instagram, Facebook digunakan sebagai akun media sosial yang akan membagikan postingan wisdom massage. Untuk menunjang informasi yang lebih banyak, pesan ini menggunakan Web untuk memberikan informasi lengkap mengenai etika pengguna smartphone. Dengan media ini diharapkan pesan dapat dengan mudah diterima oleh target/generasi milenial

\section{SIMPULAN}

Berdasarkan hasil pembahasan, dapat ditarik kesimpulan bahwa pengguatan karakter sangat penting terutama untuk Generasi Millenial. Gejala ini dianggap gejala yang wajar dan biasa saja karena mereka belum mengetahui jika hal yang mereka alami adalah gejala dari Nomophobia. Dengan adanya wisdom massage ini diharapkan generasi millenial dapat lebih memahami apa itu Nomophobia berikut dampaknya, agar mereka dapat membatasi penggunaan smartphone yang kurang penting. Selain itu kampanye ini bertujuan untuk membentuk pola pikir baru pengenai penggunaan smartphone agar muncul perilaku bijak menggunakan smartphone. Untuk menunjang keberhasilan kampanye dan penyampaian pesan maka media yang dipilih adalah media yang sangat dekat dengan Target Audience yaitu media sosial. Media ini akan dibagi berdasarkan strategi yang telah dirancang menggunakan model komunikasi AISAS (Attention, Interest, Search, Action, Share). Mulai dari menarik perhatian target, menarik rasa ingin tahu target, memberi informasi pada target, mempersuasi target hingga target membagikan informasi kepada teman-temannya melalui akun media sosial pribadinya. Sebagai reminder untuk Target Audience perancang membuat beberapa gimmick yang dapat digunakan oleh target pada aktivitas sehari-hari, sehingga dimanapun dan kapanpun target akan tetap mengingat kampanye dan pesan yang ada di dalamnya. Berikut saran untuk hasil perancangan perlu adanya pengenbangan dari visual akan pesan dapat lebih menarik perhatian target audience, pesan yang disampaikan perlu pendalaman dari segi empati 
(perasaan yang pernah target audience alami), agar target dapat lebih merasakan pengalaman yang pernah dirasakan namun terlupakan dan visual yang ditampilkan telah merepresentasikan generasi milenial. Dengan wisdom massage para pecinta smartphone khususnya generasi millennial dapat tetap bersosialisasi dan berkarakter

\section{DAFTAR PUSTAKA}

Hamid, Abdul .2018. Revolusi Industri 4.0, Peluang dan Tantangannya Bagi Pembelajaran IImu Sosial.

https://www.unimed.ac.id/2018/10/11/revolusi-industri-4-0-peluang-dan tantangannyabagi-pembelajaran-ilmu-sosial

Herwina dan Iswan, 2018. Penguatan pendidikan karakter perspektif Islam Dalam era millenial ir. 4.0.

Prosiding Seminar Nasional Pendidikan Era Revolusi "Membangun Sinergitas dalam Penguatan Pendidikan Karakter pada Era IR 4.0" Universitas Muhammadiyah Jakarta, Indonesia, 24 Maret 2018 ISSN : 2621-6477

Sjarkawi. 2006. Pembentukan Kepribadian Anak Peran Moral Intelektual, Emosional, dan Sosial Sebagai Wujud Integritas Membangun Jati Diri. Jakarta: Bumi Aksara.

Sukartono, 2018. Revolusi Industri 4.0 dan Dampaknya terhadap Pendidikan di Indonesia 